\title{
SISTEM PEMBANGKIT TENAGA SURYA SEBAGAI PENGGANTI DAYA LISTRIK PADA PERUMAHAN BTN ANAWAI KENDARI
}

\author{
Mansur \\ Jurusan Teknik Elektro Fakultas Teknik Universitas Halu Oleo, Kendari \\ Email:mansur_naufal@yahoo.com
}

\begin{abstract}
Abstrak
Kinerja sistem listrik tenaga surya dapat tergantung pada kapasitas modul yang terpasang. Semakin besar modul, maka energi listrik yang dihasilkan akan semakin besar karena semakin banyak energi radiasi matahari yang diterima oleh modul. Penelitian ini bertujuan untuk menghitung kebutuhan energi listrik dan menentukan kapasitas modul yang digunakan pada skala rumah tangga di BTN Anawai Kendari. Metode yang digunakan dalam penelitian ini adalah menggunakan perhitungan matematika dan eksperimen pada sebuah rumah yang dilengbkapi dengan panel surya di BTN Anawai Kendari. Hasil penelitian ini menunjukan bahwa kebutuhan listrik untuk rumah adalah sekitar 2053 Watt-Jam per hari. Jumlah modul yang harus disediakan untuk memenuhi kebutuhan energi listrik ini bervariasi, tergantung dari kapasitas setiap panel. Untuk kapasitas $50 \mathrm{Wp}$ (Watt-Peak), jumlah modul yang dibutuhkan adalah 8 buah, untuk kapasitas $80 \mathrm{Wp}$ jumlah modul yang dibutuhkan adalah 5 buah, sedangkan untuk kapasitas $100 \mathrm{Wp}$, jumlah modul yang dibutuhkan adalah 4 buah.
\end{abstract}

Kata Kunci : jumlah modul, matahari, kebutuhan listrik, rumah, BTN Anawai

\begin{abstract}
The solar power system as the replacement for the conventional home electricity source in BTN Anawai Kendari. The performance of solar power system depends on the capacity of the module installed. The higher the module, the higher electricity generated is, as more solar radiation energy received by the module. This study aims to quantify the electrical energy needs and to determine the capacity of the solar module utilized in a house in BTN Anawai Kendari. The method utilized in this study is to employ mathematical equations and to conduct experiments on a house equipped with the sun receiver modul in BTN Anawai. The results indicate that the electricity needs for the house is around 2053 Watt-Hours daily. The number of modules to be provided varies, depending on the panel capacity. For the panel capacity of $50 \mathrm{Wp}$ (Watt-Peak), the number of modules is 8 , for the panel capacity of $80 \mathrm{Wp}$, it is 5 , and for the capacity of $100 \mathrm{Wp}$, it is 4 .
\end{abstract}

Keywords : module number, solar, electricity needs ,house, BTN Anawai

\section{Pendahuluan}

Energi listrik sangat penting bagi kehidupan manusia. Pasokan energi nasional saat ini masih didominasi oleh energi konvensional berbasis fosil. Kebutuhan energi listrik semakin lama semakin meningkat, namun hal ini tidak diimbangi dengan jumlah pasokan energi konvensional. Oleh karena itu energi baru dan terbarukan mempunyai peranan saat ini, untuk menggurangi ketergantungan terhadap energi fosil.
Pembangkit listrik dengan panel surya merupakan salah satu teknologi yang menggunakan energi terbarukan. Penetrasi perkembangan teknologi ini pada sistem penyediaan energi yang ada saat ini telah meningkat (Bianchi dkk, 2014). Teknologi ini dapat menjadi salah satu sumber pembagkit listrik untuk menopang sebagian keperluan rumah tangga di berbagai tempat, seperti perumahan (Bien dkk, 2008). Indonesia yang merupakan daerah tropis mempunyai potensi energi matahari sangat besar karena terletak di daerah katulistiwa. 
Energi radiasi surya dapat diubah menjadi arus listrik searah dengan mempergunakan lapisanlapisan tipis dari silikon ( $\mathrm{Si}$ ) murni atau bahan semikonduktor (Kadir, 1987). Dengan kemajuan teknologi dalam pembuatan panel surya, teknologi ini telah mampu mencapai efisiensi sebesar 10\%13\% (Zuhal, 1991).

Sulawesi Tenggara merupakan salah satu provinsi di Indonesia yang memiliki potensi besar dalam pengembangan energi surya (Balaka dkk, 2013). Hal ini didukung oleh posisi geografis provinsi ini yang ada di sekitar garis katulistiwa. Sebuah kajian menunjukan bahwa potensi radiasi energi matahari di Sulawesi Tenggara adalah sekitar $1985 \mathrm{KWh} / \mathrm{m}^{2}$ per-hari (Sudia dkk, 2011).

Salah satu aspek penting dalam pemanfaatan teknologi surya di provinsi ini adalah penentuan kapasitas modul. Hal ini dapat memberikan gambaran bermanfaat bagi pengguna dalam mengaplikasikan dan dalam mengkaji nilai keekonomian teknologi ini. Tujuan penelitian ini adalah untuk menghitung kebutuhan energi listrik dan menentukan kapasitas modul surya di perumahan BTN Anawai Kendari Sulawesi Tenggara.

\section{Kajian Pustaka}

Ada berbagai jenis panel surya yang sering di digunakan saat ini ( Christina dkk, 2012). Jenis pertama panel ini adalah mono-kristal (monocrystalline). Jenis panel ini memiliki efesiensi sekitar $14 \%$ - 22\%. Panel ini mempunyai kelemahan, yaitu tidak berfungsi dengan baik apabila cuaca kurang terang. Jenis panel yang ke dua adalah Poly-kristal (poly-crystalline). Jenis panel ini merupakan panel surya yang memiliki susunan kristal acak. Jenis Poli-kristal mempunyai luas permukaan yang lebih besar dibandingkan dengan mono-kristal dan dapat menghasilkan energi pada saat cuaca yang kurang baik atau mendung. Jenis panel yang ke tiga adalah amorf. Jenis panel ini merupakan panel yang kapasitasnya terkecil dibanding dengan Mono-kristal (monocrystalline) dan Poly-kristal (poly-crystalline). Panel jenis ini memiliki teknologi yang sangat sederhana dan murah, tingkat efesiensinya hanya berkisar 6\% dan dapat bekerja pada saat cuaca kurang baik atau mendung (Christina dkk 2012).

Gambar 1 menunjukan sistem kerja sistem pembangkit listrik tenaga surya. Sistem ini terdiri dari modul surya, charge controler, accu, inverter dan beban. Modul surya merupakan sebagai tempat menerima energi radiasi matahari untuk diubah menjadi energi listrik. Charge controler berfungsi sebagai pengatur sistem agar penggunaan listriknya aman dan efektif, sehingga komponenkomponen sistem aman dari bahaya perubahan tegangan. Accu berfungsi untuk menyimpan energi dari modul surya. Inverter berfungsi untuk merubah tegangan dari DC (Direct Current) 12 Volt menjadi AC (Alternating Current) 220 Volt. Beban adalah jumlah energi yang dibutuhkan oleh beban listrik rumah tangga setiap rumah (Bient dkk, 2008 ).

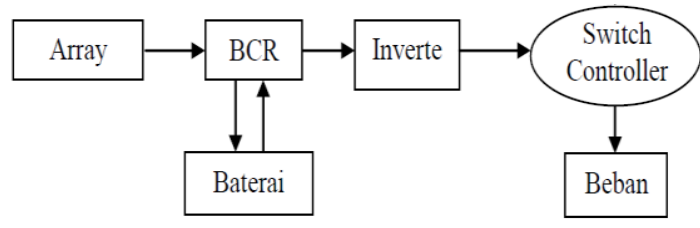

Gambar 1. Bagan alir sistem pembangkit listrik tenaga surya (Sumber : Bient dkk, 2012)

\section{Metode Penelitian}

Penelitian ini dilakukan dengan melakukan perhitungan beban listrik pada sebuah rumah di BTN Anawai Kendari. Setelah beban listrik didapatkan, langkah selanjutnya adalah menentukan kapasitas dan jumlah panel yang dibutuhkan. Dalam menentukan kapasitas dan jumlah panel, penelitian ini menggunakan dua metode, yaitu secara matematika dan secara eksperimen.

\section{Bahan dan Alat yang Digunakan}

Bahan dan alat yang digunakan adalah modul surya, baterai, pengatur $(B C R)$, inverter, lampu dan alat elektronik.



Gambar 2. Panel surya yang digunakan 


\section{DINAMIKA Jurnal IImiah Teknik Mesin}

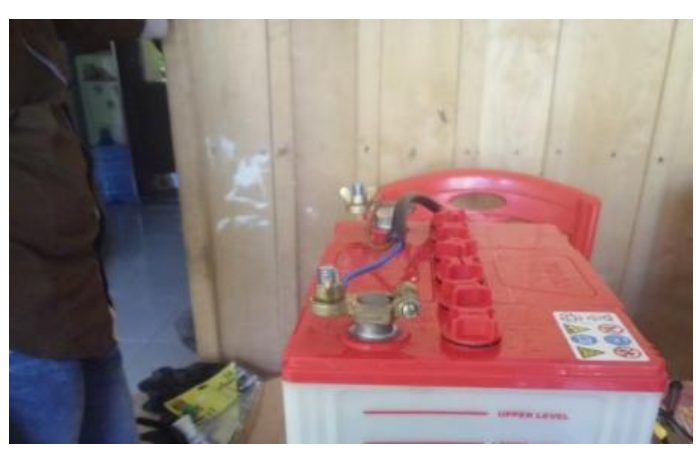

Gambar 3. Baterai yang digunakan

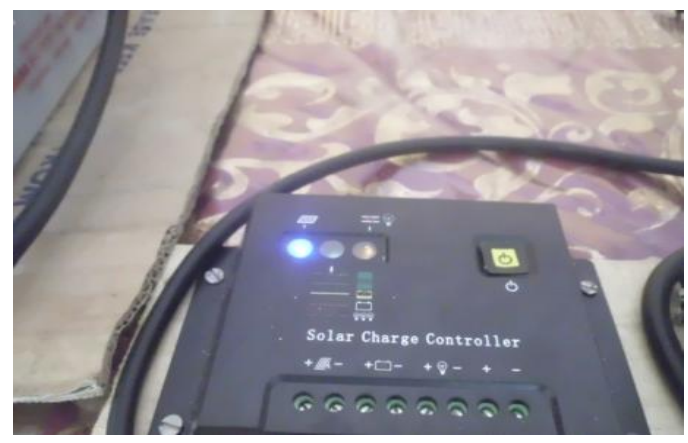

Gambar 4. Inverter

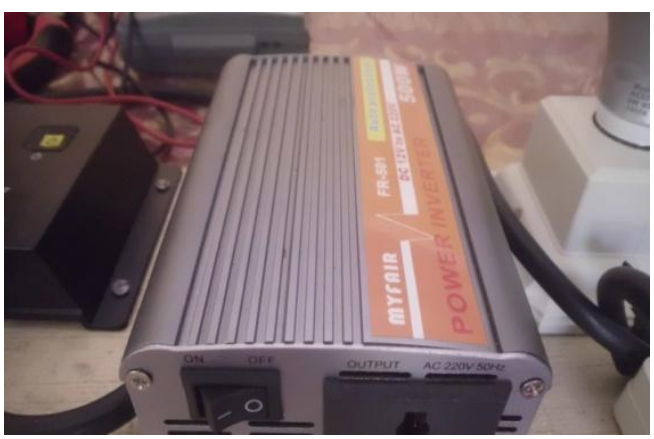

Gambar 5. Inverter (2)

Modul surya yang digunakan dalam penelitian ini memiliki daya puncak nominal (Watt-Peak) 50 $\mathrm{Wp}, 80 \mathrm{Wp}$ dan $100 \mathrm{Wp}$ (6A-8A/220VAC). Baterai memiliki kapasitas 65 Ah dan pengatur $(B C R)$ memiliki tipe BCR 8.12 dengan tegangan operasi 12 V DC.

\section{Denah BTN}

Gambar 2 menunjukan denah rumah yang digunakan dalam penelitian ini.

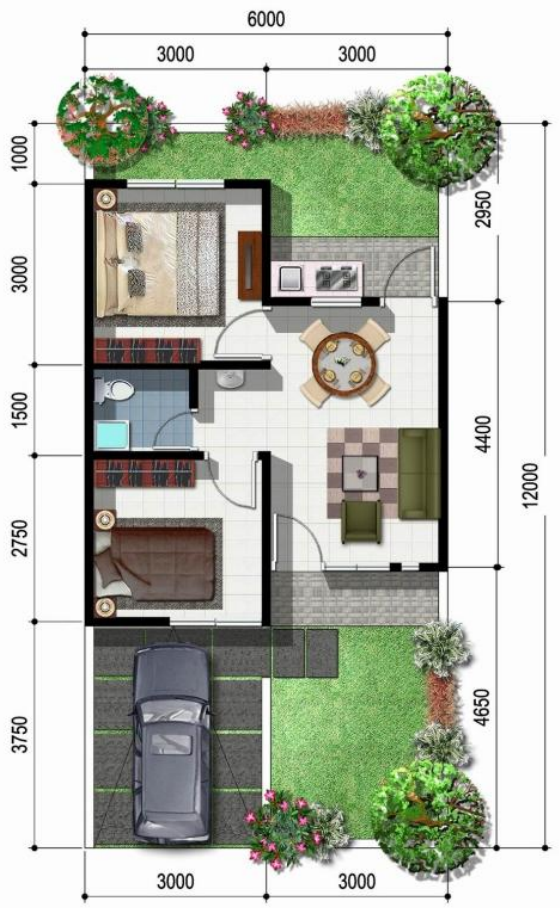

Gambar 7. Denah rumah

\section{Diagram Alir Penelitian}

Gambar berikut adalah diagram alir penelitian.

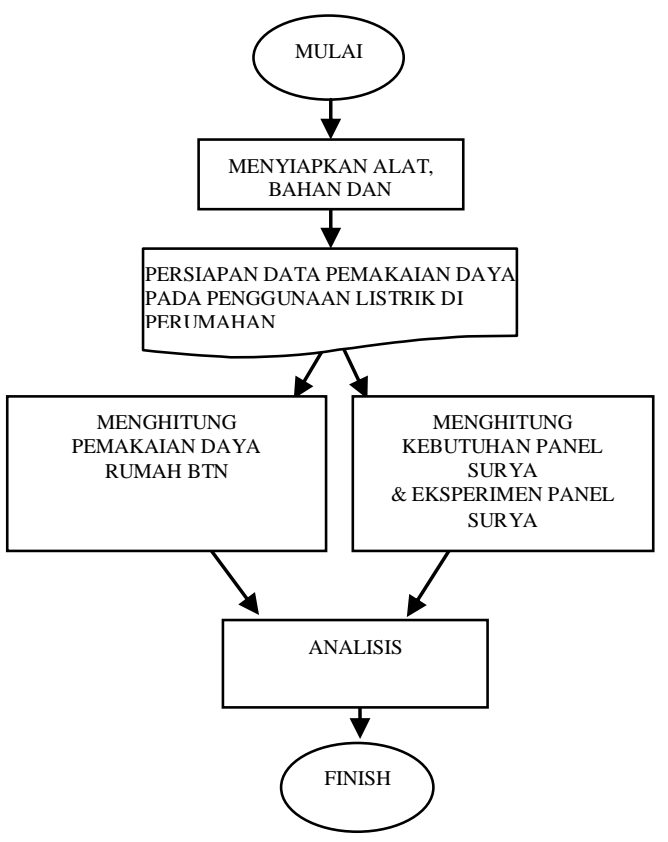

Gambar 7. Diagram alir penelitian 


\section{DINAMIKA Jurnal Ilmiah Teknik Mesin}

\section{Hasil dan Analisa}

\section{Daya, Waktu dan Energi Listrik}

Gambar 8 menunjukan hasil pengukuran daya, waktu dan energi listrik yang dibutuhkan di perumahan BTN per-hari. Dari gambar ini, total energi lsirtik yang dibutuhkan adalah 2053 WattJam per hari. Pemakaian energi ini didominasi oleh penggunaan listrik kulkas yang mencapai 960 Watt-Jam per hari, diikuti oleh setrika dan rice cooker.

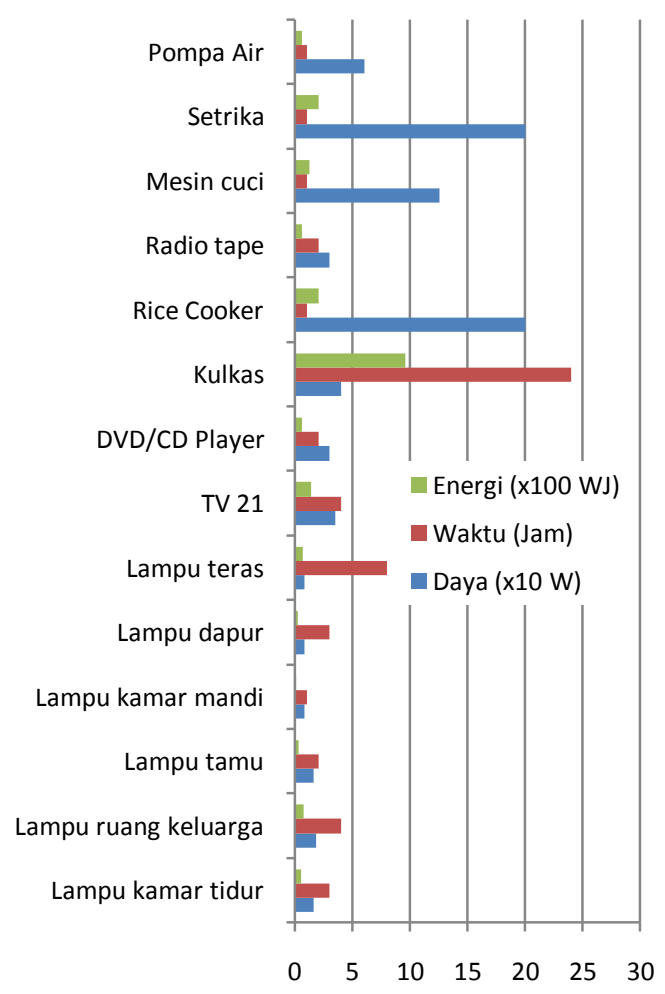

Gambar 8. Hasil perhitungan daya, energi dan waktu yang dibutuhkan

\section{Perhitungan Kebutuhan Panel Surya Secara Matematis}

Dari hasil perhitungan sebelumnya, kapasitas listrik perumahan yang dibutuhkan adalah sebesar 2053 watt. Kapasitas ini ditambahkan dengan daya sekitar $2 \%$ (untuk kebutuhan panel surya itu sendiri), menjadikan total kapasitas yang dibutuhkan sebesar

$$
\begin{aligned}
\mathrm{E}_{\text {TOTAL }} & =\mathrm{E}_{\text {nergiawal }}+20 \% \mathrm{E}_{\text {nergiawal }} \\
& =2053+(2 \% \times 2053) \\
& =2094,06 \text { watt }
\end{aligned}
$$

Untuk menentukan jumlah modul surya (N), digunakan rumus sebagai berikut :

$\mathrm{N}=\frac{\mathrm{E}_{\text {TOTAL }}}{\mathrm{T}_{\text {OTAL KAPASITAS }}}$

Dimana, total kapasitas adalah daya puncak nominal panel dikalikan jam panel operasional (dalam hal ini diasumsikan 5 jam). Tabel berikut menunjukan jumlah modul yang dibutuhkan secara matematika.

Tabel 1. Jumlah modul yang dibutuhkan secara matematika

\begin{tabular}{|c|c|c|c|}
\hline & $\begin{array}{c}\text { Modul 50 } \\
\text { Wp }\end{array}$ & $\begin{array}{c}\text { Modul 80 } \\
\text { Wp }\end{array}$ & $\begin{array}{c}\text { Modul 100 } \\
\text { Wp }\end{array}$ \\
\hline $\begin{array}{c}\text { Jumlah } \\
\text { Modul }\end{array}$ & 8 & 5 & 4 \\
\hline
\end{tabular}

\section{Penentuan Kapasitas Kebutuhan Panel Surya Secara Eskperimen}

Pada tahap berikut dipresentasikan hasil pengujian (eksperimen) modul yang digunakan untuk memenuhi kebutuhan listrik di perumahan BTN Anawai.

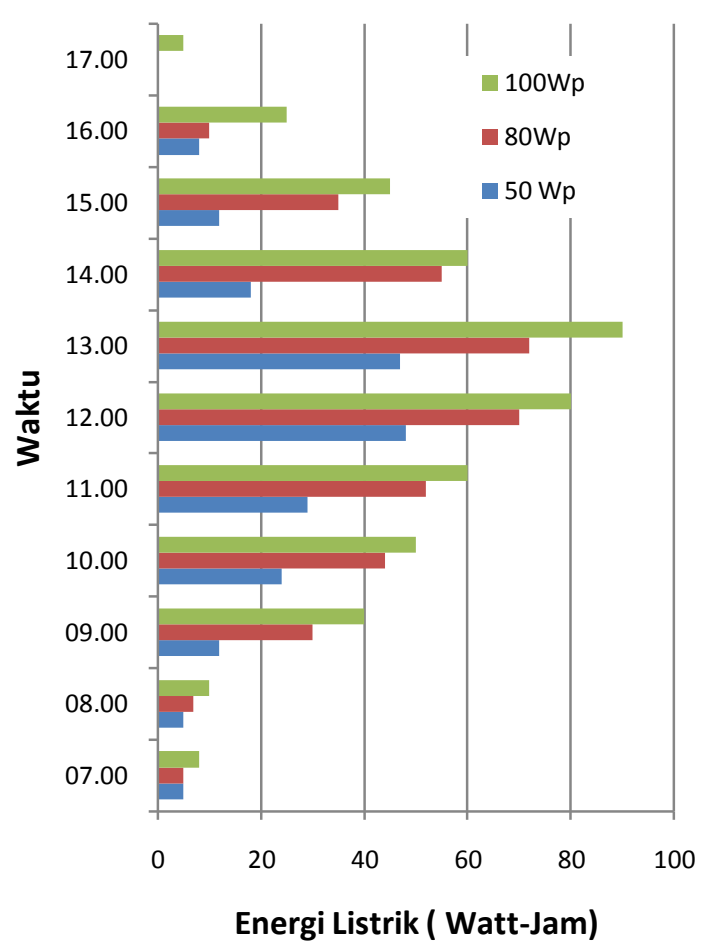

Gambar 9. Hasil pengujian energi listrik dari panel 50 $\mathrm{Wp}, 80 \mathrm{Wp}$ dan $100 \mathrm{Wp}$ 


\section{DINAMIKA Jurnal Ilmiah Teknik Mesin}

Total energi listrik yang dihasilkan oleh modul 50 Wp adalah 208 Watt-Jam, modul $80 \mathrm{Wp}$ adalah 380 Watt-Jam dan modul $100 \mathrm{Wp}$ adalah 473 Watt-Jam. Jumlah modul yang dibutuhkan dapat dilihat di tabel berikut :

Tabel 1. Jumlah modul yang dibutuhkan secara eksperimen

\begin{tabular}{|c|c|c|c|}
\hline & $\begin{array}{c}\text { Modul 50 } \\
W_{p}\end{array}$ & $\begin{array}{c}\text { Modul 80 } \\
W_{p}\end{array}$ & $\begin{array}{c}\text { Modul 100 } \\
W_{p}\end{array}$ \\
\hline $\begin{array}{c}\text { Jumlah } \\
\text { Modul }\end{array}$ & 10 & 6 & 5 \\
\hline
\end{tabular}

Dari hasil perhitungan dan eksperimen, terdapat perbedaan jumlah modul yang dibutuhkan. Perbedaan ini dapat disebabkan pada eksperimen, terdapat rugi-rugi energi (modul dan tranmisi listrik) dan pada alat ukur, yang tidak diperhitungan dalam perhitungan secara matematika. Perbedaan juga dapat disebabkan karena jumlah jam operasional yang berbeda antara metode matematika dan eksperimen.

Hasil dari perhitungan dan eksperimen juga menunjukan bahwa kapasitas modul yang besar dapat menyebakan jumlah kebutuhan modul yang lebih sedikit dibandingkan dengan modul yang memiliki kapasitas modul lebih kecil.

\section{Menghitung Kebutuhan Kapasitas Baterai}

Dalam asumsi tegangan baterai $12 \mathrm{~V}$, dan baterai digunakan per-hari habis, untuk menentukan kebutuhan kapasitasnya (AH) digunakan rumus sebagai berikut :

$$
\begin{aligned}
\mathrm{AH} & =\frac{E_{\text {TOTAL }}}{12} \\
& =\frac{2053}{12}=172 \mathrm{AH}
\end{aligned}
$$

Dari hasil perhitungan ini, kapasitas baterai yang dibutuhkan sebesar $172 \mathrm{AH}$. Kapasitas ini adalah untuk memenuhi kebutuhan energi listrik dalam rumah per-hari. Jika menggunakan baterai yang telah digunakan dalam penelitian ini (65 Ah), maka jumlah baterai yang dibutuhkan adalah sekitar 3 .

\section{Kesimpulan}

Kesimpulan dalam penelitian ini adalah jumlah modul yang harus disediakan oleh perumahan adalah bervariasi, tergantung dari kapasitas setiap penel. Untuk kapasitas $50 \mathrm{Wp}$, jumlah modul yang dibutuhkan adalah 8, untuk kapasitas $80 \mathrm{Wp}$ jumlah modul yang dibutuhkan adalah 5 sedangkan untuk kapasitas $100 \mathrm{Wp}$, jumlah modulnya adalah 4. Jumlah modul ini untuk memenuhi kebutuhan energi listrik di perumahan Anawai Kendari sebesar 2053 Watt-Jam per hari.

\section{Daftar Pustaka}

Abidin Z, Custer J. 2013, “ Desain sistim Energi Alternatif Sebagai Sumber Energi Listrik Laboratorium Listrik Dasar”. Invotek, 3 (2), 97-102.

Balaka R, Rachman A, Jaya LDM. 2013, "Mitigating climate change through the development of clean renewable energy in Southeast Sulawesi, a developing region in Indonesia". International Journal of Energy, Information and Communications, 4, 4

Bianchi M, Branchini L, Ferrari C, Melinoa F. 2014, "Optimal sizing of grid-independent hybrid photovoltaic-battery power systems for household sector", Applied Energy, Volume 136, 31 December, Pages 805-816

Bien LE, Kasim I, Wibowo W. 2008, "Perancangan Sistem Hibrid Pembangkit Listrik Tenaga Surya dengan jala-jala Listrik PLN Untuk Rumah Perkotaan". JETri, 8 (1) 37-56.

Christina EM. 2012, "Hemat Energi dan Lestari Lingkungan melalui Bangunan".

Kadir A. 1987, “Energi”, UI-Press, Jakarta.

Sudia B, Rachman A. 2011, "The assessment of solar radiation intensity in Southeast Sulawesi based on the relative position of the sun". Jurnal Metropilar, Vol 9, 2/4/2011, p 115 - 120, ISSN 1693-6205

Zuhal,1991, "Dasar Tenaga Listrik”, Penerbit Bandung. 
DINAMIKA Jurnal Ilmiah Teknik Mesin 